\title{
HOW CAN UNIVERSITY LEARNING ENVIRONMENT CONTRIBUTE TO STUDENTS' CREATIVITY? LITHUANIAN STUDENTS’ PERSPECTIVE
}

\author{
Nijolè BURKŠAITIENE ${ }^{*}$ \\ Mykolas Romeris University, Institute of Humanities, Lifelong Learning Laboratory, \\ Ateities str. 20, LT-08303, Vilnius, Lithuania
}

Received 21 February 2018; accepted 23 July 2018

\begin{abstract}
Students' creativity has been increasingly researched in higher education. Until recently, however, empirical studies investigating students' views of how universities can contribute to the development of their creativity have been rare. The present study aims to investigate how university learning environment can contribute to undergraduate philology students' creativity as seen by the students themselves. The data were collected through questionnaires and analysed using qualitative research method of content analysis.

The general conclusion of this study is that the study participants consider that universities can foster their students' creativity in some ways. Firstly, they think that university curriculum should contain assignments aimed at developing student creativity. Prominent among the findings was the students' belief that their university teachers are important contributors to this process. Besides, the students considered that their creativity can be developed by introducing a special study subject, by enhancing their transferable skills, and that more collaborative learning and special university events could make an impact on their creativity. On the other hand, the results of the present study have also revealed some challenges that call for further research.
\end{abstract}

Keywords: collaborative learning, creative assignments, creativity, creativity-aimed study subject, higher education, students' views, teachers' support, transferable skills, university contribution to creativity development.

\section{Introduction}

In recent years, creativity has been widely investigated at all levels of education, higher education including (Sternberg, 2006; Beghetto, 2010; Davis, Keegan, \& Gruber, 2012; Y. Yeh, Y. Yeh, \& Chen, 2012; Zenasni \& Lubart, 2011; Mansoor, 2010; Sarrimo, 2010; GrakauskaitèKarkockienè, 2006; Šliogerienè, 2013; Burkšaitienè, 2013, 2014). The literature illustrates that to analyse and understand creativity, a multitude and diversity of theoretical perspectives, assumptions and methods have been employed. This is due to the extremely complex nature of

*Corresponding author. E-mail: n.burksaitiene@mruni.eu 
this phenomenon, which makes it not possible for one theory or a sole method to serve the purpose of analysing all its aspects. Therefore, the choice of a theoretical approach to be used to investigate creativity largely depends on the aspect(s) of creativity which is/are to be studied. These include the four traditional aspects, also called the four "P's of creativity" (i.e. creativity understood as a process, product, person (or personality) and place (or press)), as well as the aspects of persuasion and potential, which have been recently added to the list (Kozbelt, Beghetto, \& Runco, 2010). Aaron Kozbelt, Ronald A. Beghetto and Mark Runco (2010) analysed the existing theories of creativity and distinguished ten major categories depending on the aspect(s) of creativity that they emphasise. The ten major categories include developmental, psychometric, economic (also called investment), stage and componential process, cognitive, problem-solving and expertise-based, problem-finding, evolutionary, typological and systems theories of creativity. The developmental theories of creativity state that creativity develops over time. They help us to understand the origins of creativity and disclose the pivotal role which the environment plays in the process of leading a person's creative potential to be fulfilled and turned into creative achievements. In contrast, the psychometric theory of creativity focuses mainly on the product and measures its creativity in terms of assessment of its reliability and validity. Economic or investment theories of creativity are concerned with creative ideas and behaviour that are influenced by the marketplace and economy, whereas stage and componential process theories deal with the creative process and seek to understand its structure and nature.

Cognitive theories of creativity and the theories of creativity that are based on problemsolving and expertise both focus on the creative process and person but analyse them from a different perspective. The former theories of creativity stress the role of cognitive mechanisms as a basis for creative thought in the creative process and consider individual differences in such mechanisms. The latter theories analyse the creative process to understand how traditional cognitive psychological concepts explain how people generate creative solutions to problems and stress domain specific expertise as a prerequisite for significant personal creative achievements. The problem-finding theory, on the other hand, is mainly a theory of the creative process. It holds that the traditional problem-solving view:

"[...] is inadequate to explain how creators come to realize that a problem exists in the first place, and how they are motivated to proactively bring their subjective experience to understand the problem" (Kozbelt et al., 2010, p. 34).

The evolutionary, typological and systems theories of creativity focus on all six aspects of creativity, i.e. on the creative process, person, product, place, potential and persuasion, however, their sources and aims differ. To illustrate, evolutionary theories of creativity draw from evolutionary biology and aim to understand the nature of genius, eminence, and Big$\mathrm{C}$ achievements, whereas typological theories of creativity seek to understand individual differences in creators' personalities, working methods, career trajectories, etc. According to Kozbelt, Beghetto and Runco (2010), systems theories of creativity are the most ambitious as they take a broad contextual view of creativity. These theories hold that:

"[...] creativity is best conceptualized not as a single entity, but as emerging from a complex system with interacting subcomponents - all of which must be taken into account for a rich, meaningful, and valid understanding of creativity" (Kozbelt et al., 2010, p. 38). 
In the context of the present study, it should be mentioned that according to the investment theory of creativity, to become creative, one's personal decision and a confluence of six creativity components, including intellectual ability, knowledge, styles of thinking, personality, motivation, and the environment are crucial (Sternberg, 2006). What is more, according to this theory, creativity is not a simple sum of a personally acquired level of each of these components but rather their confluence. Besides, it is important that there exist thresholds for some of the components below which creativity is not possible (e.g., knowledge). On the other hand, one component (e.g., motivation) may partially compensate for the weakness of another component (e.g., the environment), whereas the interaction of two components (e.g., intelligence and motivation) may significantly enhance creativity (Sternberg, 2006).

It is reported in the literature that all six aspects of creativity have been widely investigated, including the place (or press) which corresponds to Robert Sternberg's (2006) creativity component called "the environment". It has been established that creativity tends to flourish in the environment where " $<\ldots>$ there are opportunities for exploration and independent work, and when originality is supported and valued" (Kozbelt et al., 2010, p. 25). It has been also established that challenges arising from an environment can be created by negative feedback provided to learners or that evaluation conducted within an environment can predetermine the growth of creativity (Sternberg, 2006). In Lithuania, however, university learning environment and its impact on learners' creativity has not been investigated much (Grakauskaitè-Karkockienè, 2006; Šliogerienè, 2013; Burkšaitienè, 2013, 2014). The present study aims to analyse undergraduate philology students' views of how university learning environment can foster their creativity. It will first elaborate on the theoretical framework. There then follows the explanation of the research methodology describing the context of the research and research limitations. The findings of the investigation of the students' views of how university can contribute to their creativity will be then discussed. To carry out the research, qualitative methodology of content analysis was used.

\section{Theoretical framework}

The present research is based on the investment theory of creativity and its central assumption that creativity is neither a mental ability nor a personal feature, thus it can be taught and learnt (Sternberg, 2006; Nettle, 2009). According to this theory (Sternberg, 2006), to foster creativity, two aspects are particularly important, i.e. a personal decision and a confluence of six distinct but interrelated creativity components (called "resources"), including intellectual abilities, knowledge, styles of thinking, personality, motivation and the environment.

From the investment theory perspective, to become creative, a person should possess intellectual abilities that combine three main skills, including the synthetic skill, analytic skill, and practical-contextual skill (Sternberg, 2006). The author notes that the synthetic skill allows a person to see problems in new ways, the analytic skill allows a person to select the ideas that are worth pursuing, whereas the practical-contextual skill helps one to persuade others to believe in one's ideas. The second component of creativity is knowledge. It is the component for which a threshold level is required below which creativity is not possible. The third component is thinking styles, which Sternberg describes as "preferred ways of using 
one's skills" (2006, p. 89). The author states that "legislative style" of thinking is particularly relevant for creativity. It is defined as "a preference for thinking and a decision to think in new ways" and as the ability to think globally as well as locally (Sternberg, 2006, p. 89). The fourth component is related to personality and its attributes, which includes willingness to overcome obstacles, willingness to take sensible risks, willingness to tolerate ambiguity, and self-efficacy. Intrinsic, task-focused motivation is also essential for creativity. According to the author, motivation is not something inherent, it is based on one's decision to be motivated by one thing or another. Finally, supportive environment is the component which also plays a relevant role in the process of creativity development. According to Sternberg (2006), environments typically are not fully supportive regarding one's creativity, therefore, to foster it, both the learner's perspective and the resources should be considered.

It is reported in the literature that creativity in higher education has been widely researched. For example, Asma Mansoor (2010) investigated Pakistani students' difficulties in a course of creative writing in order to help them in the areas of vocabulary development, to minimize first language interference, and to develop a practical approach to grammar as well as an innovative, out-of-the box thinking and expression. The researcher investigated students' approaches towards the study subject, identified the major difficulties that they faced during the process of learning, and established a number of writing activities which best supported students' creative writing skills. In another example, Joseph M. Rein (2011) discussed the use of creative research at the university. He distinguished between experiential and traditional creative research methods, analysed their role for teaching and learning creative writing and argued that traditional creative research methods (such as reading textbooks, examining primary source material and scanning recent journals) are often overlooked within academia. Rein (2011) suggested to integrate them in university writing classrooms and proposed an example easily modifiable to various texts and genres. Franck Zenasni and Todd Lubart (2011), on the other hand, investigated the relationship between undergraduate students' perceived pleasantness of creative story writing and their creative performance. The findings of their research showed that overall perceived pleasantness did not differ between tasks. The results also indicated that the study participants' perceived pleasantness of the story writing task increased during the task completion, whereas the perceived pleasantness of the divergent thinking tasks did not change during the task performance. Hannes Zacher and Emily Johnson (2015) analysed leadership and creativity in doctoral studies. They explored the relationships between $\mathrm{PhD}$ students' perceptions of their advising professors' behaviours and the professors' ratings of their students' work-related creativity. The results of their study demonstrated that even though doctoral students' perceptions of the professors' transformational leadership positively predicted the ratings of the students' creativity, their perceptions of the professors' passive-avoidant and transactional leadership did not significantly predict professors' ratings of students' creativity.

In Lithuania, the most recent research has focused on the impact of academic environments on students' creativity and creativity-related cognitive abilities. To illustrate, Daiva Grakauskaite-Karkockienè (2006) created a programme aimed to develop future teachers' cognitive abilities of fluency, flexibility and originality and investigated its effectiveness. The research results revealed that the study participants perceived the programme as very useful 
as it contributed to the development of their own creative abilities, made an impact on their views regarding their abilities to be creative and original, to generate new ideas, as well as raised their curiosity towards creativity. In another example, Jolita Šliogerienè (2013) studied the impact of undergraduate students' self-reflection on creativity in a portfolio-based learning environment in a course of legal English. The researcher concluded that writing self-reflection pages in the language learning portfolio during the course was useful, that it fostered students' self-regulation skills and encouraged their creative thinking. Nijole Burkšaitiene (2013) analysed the impact of project-based learning environment on students' creativity in a course of English for specific purposes. It was established that project-based learning promoted students' knowledge in the field of their study, developed their foreign language skills and transferrable skills, and fostered their creativity. However, empirical research exploring Lithuanian students' views of university contribution regarding their creativity development has not been reported in the literature. The present study aims to investigate how university learning environment can contribute to undergraduate philology students' creativity as seen by the students themselves. To answer this research question, qualitative methodology of content analysis was used.

\section{Research methodology}

The present study is part of a larger mixed-method research aimed to explore undergraduate philology students' views regarding their creativity development employing both qualitative and quantitative research methods. The data were collected through a questionnaire which consisted of 21 questions. The opening section introduced the respondents to the topic, informing them that the questionnaire was designed to understand their views regarding their personal creativity, to get an insight into creativity-related activities that they participate in, as well as to analyse their views of how the university can contribute to the development of their personal creativity. The questionnaire consisted of a structured part (17 questions) and an open-ended part (4 questions). The present paper reports only on the findings from the qualitative analysis of the data regarding their views of how university learning environment can foster their creativity. It is recommended that the present study be extended to the investigation of the students' views regarding their personal creativity and their engagement in creativity-related activities.

Another limitation of the present investigation is the number of its participants. This limitation does not allow for wide generalisations.

\section{Participants, the instrument and the procedure}

The present study was conducted with the participation of 39 undergraduate students of English philology from two universities in Lithuania. The students' average age was 21 . The study participants were asked to fill in questionnaires which contained both a structured part and an open-ended part. All answers were held anonymous and presented on a voluntary basis.

The open-ended part of the questionnaire included the following four questions: (1) "Are you a creative person? If yes, in what way?"; (2) "What do you like about creative writing the most?"; (3) "What do you find the most difficult when you are given a creative task (e.g. to 
write a composition, an essay, a short story, a project, etc.)?"; (4) "How, in your opinion, can your university contribute to the development of students' creativity?". This study reports on the results of qualitative analysis of the students' responses to the last open-ended question. To analyse the students' views, the research method of content analysis was used. First, the students' responses were analysed, then the emerging themes were established, analysed and categorised. As the result, six categories of the ways how university learning environment can foster students' creativity were identified, further analysed, and sub-categories identified. Finally, the categories and sub-categories were supplemented with samples of evidence. It should be mentioned here that all responses provided by the students were taken into consideration, which resulted in the identification of some categories that were supported by only a few samples of evidence.

\section{Results}

To gain insights into the students' views, content analysis of their responses to the openended question "How, in your opinion, can university contribute to the development of students' creativity?”. Responses were provided by $79 \%(n=31)$ of the study participants, some of them presented more than one answer to the given question. The analysis of the emerging themes resulted in the identification of six categories of the ways how university learning environment can foster students' creativity, which included introducing creative assignments, teachers' support, introducing a special study subject, developing students' collaborative learning, enhancing students' transferrable skills, and organising special events at the university.

Category 1: introducing creative assignments. It was reported by 19 study participants that university learning environment could contribute to their creativity development if their curriculum contained more creative assignments. The students considered that diverse writing tasks such as writing on student-chosen topics, on free topics, on their favourite books, movies, hobbies, and other creative writing tasks (e.g., writing essays, poems or short stories) would remarkably contribute to their creativity. This can be illustrated by the following extracts from their responses: "I believe that writing tasks give a lot of space for creativity. Some students may find that they like writing essays <... > and "Some tasks, like writing a poem on a lecture topic could be useful [...]" or "[...] assignments related to students' hobbies and their favourite books, movies, etc. could support our creativity". The students also reported that "Doing more creative tasks", "More diverse tasks", "Being given creative tasks for homework" could foster their personal creativity. Also, they considered that "Encouraging students to do more creative tasks" and "Giving students an opportunity to turn their ideas into reality" would have a positive impact on their creativity.

On the other hand, the finding that "More writing tasks (but not speaking tasks) could do that because usually it it's too stressful as you are afraid that someone will make fun of you" is thought-provoking. It shows that the student acknowledged that s/he did not want to express her/his thoughts freely in the classroom because of the fear of being made fun of, which calls for looking into the reasons causing such a fear and which can be a challenging task for university teachers. 
Category 2: teachers' support. Six students viewed that university teachers being part of the university environment can make a remarkable contribution to their creativity. They believed that it can be done by raising students' awareness of the nature of creativity. To illustrate, they stated that teachers "[...] should raise student awareness that there can be various ways of creativity [...]. Everyone can find a field in which they will feel creative". This sample of evidence suggests that the student did not have enough knowledge regarding the main six aspects of creativity.

An interesting finding was the students' view that university teachers can also contribute by "broadening students' world view in various lectures" and by supporting non-traditional thinking. It is best illustrated by these examples: "A teacher should let students be more openminded", "At the university we should sometimes think in another way, should do some tasks, not in a logical way, so that by doing such tasks we could develop our creativity" and "We should have tasks that require more than one way to solve them [...]". The latter responses support Sternberg's (2006) findings that to be creative, one should develop legislative thinking style which is thinking in new ways.

An important finding of this study was the students' belief that their creativity can be fostered by teacher-provided psychological support, i.e. by supporting students' self-confidence and courage (reported by 2 students). They stated that "Teachers could encourage students to trust themselves and be independent thinkers who would not be afraid to state their opinion" and that "They could support creative students and unleash their inner courage; help students follow the way that leads to creativity". This suggests that some students do feel lack of selfconfidence and leads to the assumption that university teachers should ask their students how they feel and provide support to those who really need it.

Category 3: introducing a special study subject. Five students viewed that their creativity can be developed by introducing a special study subject in their study programmes. They reported that "There could be special classes for creativity development", that "Seminars on the subject of creativity would contribute to fostering student creativity" or that it would be useful "To have modules that teach creative writing" as well as "To organise creative writing workshops" and "Give students an opportunity to turn their ideas into reality". This is in line with the investment theory of creativity and the theories of creativity based on problemsolving and expertise that stress that there exists a threshold level of knowledge below which creativity is not possible and that domain specific expertise is a prerequisite for significant personal creative achievements (Sternberg, 2006; Kozbelt et al., 2010).

Category 4: developing students' collaborative learning. Four students stated that their creativity can be fostered by team work and pair work. To illustrate, they said that creativity can be fostered if they "[...] have more group projects", "[...] worked in pairs/groups", "[...] played educational games" and "[...] worked in pairs and came up with some short story". These findings are in accord with Kozbelt, Beghetto and Runco (2010) who stated that creativity tends to flourish in the environment which provides opportunities for exploration, as well as with the findings of Burkšaitienè (2013) who established that project-based learning, which is based on collaboration, had a positive impact on law students' creativity.

Category 5: enhancing students' transferrable skills. Three students responded that to foster creativity, students' presentation skills should be developed: "Universities could let students 
make more presentations" (reported by two students) and that "Presentations on free topics would be beneficial", indicating that public speaking is seen as a way of enhancing personal creativity.

Category 6: organising special events. Two students believed that various events organised at the university would contribute to their creativity development, which is illustrated by these responses: "Events organised at the university may inspire some of the students" and "Some exhibitions of paintings that students created or some music contests [...], but they should be not compulsory". The latter opinion illustrates that the element of freedom to choose to participate or not to participate in the events is important to the respondent, which corroborates Sternberg's (2006) assumption that to foster creativity, one should make a decision to do so.

\section{Conclusions}

The general conclusion of the present study is that the students view their universities as the learning environments that can contribute to the development of their creativity. It is important that the students clearly expressed their views regarding the ways how it can be fostered, which is in line with the investment theory of creativity that holds that creativity is neither a mental ability nor a personal feature, and, therefore, it can be taught and learnt (Sternberg, 2006).

More specifically, it can be concluded that the study participants considered that their creativity can be fostered through the university curricula, i.e. through diverse learning assignments designed to promote creativity or to disclose the potential of students' creativity. This is in accord with the developmental theories of creativity that stress the pivotal role which the environment plays in the process of leading a person's creative potential to be fulfilled and turned into creative achievements (Kozbelt et al., 2010).

It can be also concluded that some study participants viewed university teachers as important contributors to the process of developing their creativity, i.e. the students stated that university teachers can contribute by promoting students' open-mindedness, legislative style of thinking and by providing psychological support to those students who may need it. At this point it is vital to know whether university teachers are aware of their students' views and what opinions regarding their own role in the process of developing students' creativity they hold. It can be hypothesised that if the students and university teachers' views regarding university teachers' role and their contribution to the process of creativity development match, a common curricular goal to foster the creative competence of students can be established. This corroborates Beghetto's view (2010, p. 447) that developing the creative competence is relevant as it will help students to function successfully in the increasingly complex and ill-defined nature of life in the 21st century. Therefore, further research aimed to identify university teachers' views regarding the development of students' creative competence at the university would be valuable.

The research results also showed that the students linked their creativity development with the enhancement of their transferrable skills and collaborative learning, with a special university study subject, as well as with the participation in special university events that 
could provide them with an opportunity to demonstrate their creativity achievements. These findings allow to conclude that the students are aware of what they need to become creative, which includes not only practical skills and abilities, but also specific knowledge and willingness to demonstrate their creative products. This is in line with the central assumption of the investment theory of creativity, i.e. that creativity requires a personal decision and a confluence of resources, including willingness to participate in the process, intellectual skills and knowledge for which a threshold level below which creativity is not possible is required (Sternberg, 2006).

On the other hand, the results of the present research also disclosed that to foster student creativity within academia successfully, some challenges should be considered. They include student-reported lack of self-confidence and unwillingness to express one's thoughts freely in the classroom, the latter being attributed to the fear of being made fun of. These challenges are thought-provoking and call for further research so that the reasons causing them could be identified and eliminated.

Finally, a study participant stated that "There're no ways you can make a person be creative or even make him want to be creative", which is in line with the investment theory of creativity which stresses that creativity is a personal decision (Sternberg, 2006). On the other hand, this statement is real a challenge to the university as it raises a question: can university learning environment inspire students to make such a decision?

\section{References}

Beghetto, R. A. (2010). Creativity in the classroom. In J. C. Kaufman \& R. J. Sternberg (Eds.), The Cambridge handbook of creativity (pp. 447-463). Cambridge: Cambridge University Press. https://doi.org/10.1017/CBO9780511763205.027

Burkšaitienè, N. (2014). Creative writing at the university: students' perceptions and expectations. Societal Studies, 6(3), 661-671. https://doi.org/10.13165/SMS-14-6-3-13

Burkšaitiené, N. (2013). Project-based learning for the enhancement of self-regulated learning and creativity in a course of ESP. In R. Bebre (Ed.), Creative personality, Vol. 11 (pp. 164-172). Riga: Riga Teacher Training and Education Management Academy.

Davis, S. N., Keegan, R. T., \& Gruber, H. (2012). The evolving systems approach. In M. A. Runco (Ed.), The creativity research handbook. Vol. 2 (pp. 199-231). New York, N.Y: Hampton Press.

Grakauskaitè-Karkockienė, D. (2006). Pedagoginio profilio studentų kūrybiškumo pokyčiai. Acta Paedagogica Vilnensia, 17, 66-77. https://doi.org/10.15388/ActPaed.2006.17.9686

Kozbelt, A., Beghetto, R. A., \& Runco, M. A. (2010). Theories of creativity. In J. C. Kaufman \& R. J. Sternberg (Eds.), The Cambridge handbook of creativity (pp. 20-47). Cambridge: Cambridge University Press. https://doi.org/10.1017/CBO9780511763205.004

Mansoor, A. (2010). Teaching creative writing to university level second language learners in Pakistan. New Writing: The International Journal for the Practice and Theory of Creative Writing, 7(3), 201-218. https://doi.org/10.1080/14790726.2010.514052

Nettle, D. (2009). The evolution of creative writing. In S. B. Kaufman \& J. C. Kaufman (Eds.), The psychology of creative writing (pp. 101-116). Cambridge: Cambridge University Press.

Rein, J. M. (2011). Write what you don't know: teaching creative research. New Writing: The International Journal for the Practice and Theory of Creative Writing, 8(2), 96-102.

https://doi.org/10.1080/14790726.2010.542247 
Sarrimo, C. (2010). Creative writing as a communicative act - an artistic method. New Writing: The International Journal for the Practice and Theory of Creative Writing, 7(3), 179-191. https://doi.org/10.1080/14790726.2010.509509

Sternberg, R. J. (2006). The nature of creativity. Creativity Research Journal, 18(1), 87-98. https://doi.org/10.1207/s15326934crj1801_10

Yeh, Y., Yeh, Y., \& Chen, Y.-H. (2012). From knowledge sharing to knowledge creation: a blended knowledge-management model for improving university students' creativity. Thinking Skills and Creativity, 7(3), 245-257. https://doi.org/10.1016/j.tsc.2012.05.004

Šliogerienè, J. (2013). Fostering creativity through self-reflection. In R. Bebre (Ed.), Creative personality, Vol. 11 (pp. 37-43). Riga: Riga Teacher Training and Education Management Academy.

Zacher, H., \& Johnson, E. (2015). Leadership and creativity in higher education. Studies in Higher Education, 40(7), 1210-1225. https://doi.org/10.1080/03075079.2014.881340

Zenasni, F., \& Lubart, T. (2011). Pleasantness of creative tasks and creative performance. Thinking Skills and Creativity, 6(1), 49-56. https://doi.org/10.1016/j.tsc.2010.10.005

\title{
KAIP UNIVERSITETO STUDIJŲ APLINKA GALI UGDYTI STUDENTŲ KŪRYBIŠKUMĄ? LIETUVOS STUDENTŲ POŽIŪRIAI
}

\author{
Nijolè BURKŠAITIENE்
}

\begin{abstract}
Santrauka
Studentų kūrybiškumo ugdymo aukštajame moksle tematika jau sulaukè didelio užsienio tyrèjų dèmesio, tačiau Lietuvoje dar pasigendama empirinių tyrimų, analizuojančių studentų požiūrius, kaip universiteto studijų aplinka gali prisidèti prie jų kūrybiškumo ugdymo. Šiuo tyrimu siekiama nustatyti filologijos bakalauro studijų studentų požiūrius, kaip universiteto studijų aplinka gali plètoti jų kūrybiškumą. Tyrimo duomenys buvo gauti anketinès apklausos būdu ir išanalizuoti taikant kokybinio tyrimo turinio analizès metodą.

Tyrimo rezultatai rodo, kad, studentų požiūriu, jų universitetai yra ta mokymosi aplinka, kuri yra palanki studentų kūrybiškumui plètoti. Svarbu tai, kad tyrimo dalyviai aiškiai ịvardijo būdus, kaip tai gali būti ịgyvendinta. Pirma, studentai nurodè, kad didesnio skaičiaus kūrybiškumą skatinančių užduočių ịtraukimas ị universitetų studijų programas turètų teigiamą poveikị jų asmeniniam kūrybiškumui. Svarbus šio tyrimo rezultatas - dalies studentų išreikštas požiūris ị universiteto dẻstytojų vaidmenị šiame procese, t. y. dalis studentų nurodè, kad dèstytojai, būdami integralia universiteto studijų aplinkos dalimi, gali reikšmingai prisidèti prie jų kūrybiškumo ugdymo. Be to, tyrimo metu nustatyti ir kiti būdai, kurie, studentų nuomone, turètų teigiamą îtaką studentų kūrybiškumo plètotei, t. y. specialiai tam skirtas universiteto studijų dalykas, studentų keliamųjų gebejimų ugdymas, mokymosi bendradarbiaujant skatinimas ir specialūs universitete organizuojami renginiai. Kita vertus, šio tyrimo rezultatai taip pat atskleide studentų kūrybiškumui ugdyti kylančius iššūkius.
\end{abstract}

Reikšminiai žodžiai: mokymasis bendradarbiaujant, kūrybinès užduotys, kūrybiškumas, kūrybiškumui skirtas studijų dalykas, aukštasis mokslas, studentų požiūriai, dèstytojų parama, keliamieji gebejimai, universitetų indèlis plètojant kūrybiškumą. 